\title{
Protests, Pandemics, and Political Participation: Voter Turnout in Georgia in the 2020 Elections
}

\author{
Kiela Crabtree* $\quad$ Bernard L. Fraga ${ }^{\dagger}$
}

September 25, 2021

\begin{abstract}
Georgia became the focus of nationwide attention with a narrow margin of victory for Joe Biden in the 2020 presidential election and similarly narrow runoff victories for Democrats that gave the party a majority in the U.S. Senate. However, these elections came at the end of a year that saw the COVID-19 pandemic and resurgent Black Lives Matter (BLM) protests, two events which created tremendous upheaval in the everyday lives of Georgians and Americans more broadly. In this study, we consider how pandemic-related shifts in election administration and racial justice protest activity impacted political participation in 2020 primary and general elections in Georgia. Using a comprehensive statewide voter file, including data on the self-reported race and validated turnout of over 7 million registered Georgians, we analyze the combined effect of these events on racial differences in voter turnout rates, methods, and timing. We find that despite a general shift to mail balloting, Black voters were significantly more likely to vote in person during the height of the pandemic than White Democrats. These voters were later less likely to vote by mail (or vote at all) in November, despite historic mobilization efforts. We also demonstrate that Black voter turnout was significantly higher in the period following the most intense racial justice protests in Georgia than it was for Whites, Latinxs, or Asian Americans. The results of this study indicate how election reforms and non-electoral mobilization can shape turnout disparities even among highly engaged voters.
\end{abstract}

${ }^{*}$ Ph.D. Candidate, Department of Political Science, University of Michigan (crabtka@umich.edu)

${ }^{\dagger}$ Associate Professor, Department of Political Science, Emory University (bernardfraga@emory.edu) 


\section{Introduction and Background}

The national spotlight swung to the state of Georgia on the night of November 3, 2020 as the state's 16 electoral votes for president were awarded to then-Democratic nominee Joe Biden. Prior to the 2020 Presidential election, the state had not gone for a Democratic presidential candidate since 1992. That same night, Georgia also established itself as pivotal in determining the U.S. Senate majority, with both of its Senate races proceeding to a runoff election. Before national attention turned to Georgia, however, Georgia voters faced significant challenges to political participation that many felt would disproportionately impact Black Georgians. In a year that was engulfed by the COVID-19 pandemic and roiling racial justice protests, this paper considers and contextualizes how these factors influenced racial differences in voter turnout across both the primary and general elections.

There is a well-noted gap in voting participation across the country when comparing across racial groups (Fraga 2018). Specifically, racial and ethnic minorities are less likely to vote than non-Hispanic whites, disparities that have persisted over time, are often exacerbated by socioeconomic differences, and interact with facially race-neutral election administration policies. However, two occurrences in 2020 potentially exacerbated these disparities further. The year saw the ongoing COVID-19 pandemic and resurgent Black Lives Matter protests, events that had a particularly strong impact in Georgia given the high COVID case rate and attention paid to protests in metro Atlanta. When examined in conjunction with the 2020 presidential primary and general elections, we expect that these phenomena impacted voter turnout in Georgia in two distinct ways.

First, with the Georgia presidential primary on the horizon, the onset of the COVID19 pandemic and subsequent state-of-emergency and shelter-in-place orders demanded that determined voters cast their voters in alternative ways. The Georgia Secretary of State made a concerted effort to encourage absentee-by-mail voting by opening the option to all voters 
in the state, in addition to sending all registered Georgia voters an application to apply for an absentee mail-in ballot. ${ }^{1}$ However, national and state survey data indicates that African-American voters retained a preference for in person voting over mail-in absentee ballots. Therefore, we suspect that the shift to absentee-by-mail voting may have further widened the turnout gap between white and African-American voters in Georgia's June 9, 2020 primaries and the subsequent presidential election in November 2020.

Second, we predict that protest mobilization across the county in the summer of 2020 that focused on racial injustice and police brutality crossed over into the realm of electoral politics. We expect that these protests impacted early-voting in one of two ways - spurring the engagement of either Black or white voters through distinct pathways. These pathways predict either increased Black voting (relative to whites) or the reverse.

To test these expectations, we use Georgia's publicly available statewide voter data, including the voter registration list, voter absentee lists, and vote history data, to quantify demographic differences in rates of voter turnout and methods of voting in Georgia's 2020 elections. We find evidence that Black primary voters became significantly more likely than whites to not shift to absentee-by-mail in either the primary or general elections. Yet, we also see that racial justice protests during the early in-person voting period plausibly propelled Black voters to a higher likelihood of turning out to vote - notably, to turn out in person in the midst of a global pandemic and police countermobilization.

\section{Sheltering in Place and Shutting Down the Vote}

Scholars have noted the ways in which administrative restrictions on voting (Hajnal, Lajevardi and Nielson 2017; Highton 2017), direct or proximate interaction with the criminal justice system (Burch 2013; Walker 2020), and long lines to vote (Pettigrew 2017; Pettigrew

\footnotetext{
${ }^{1}$ Prior to the COVID-19 pandemic, only Georgians 65 or older, with physical disabilities, or in the armed services were permitted to cast an absentee-by-mail ballot.
} 
2021) create obstacles for citizens, and particularly citizens of color, to overcome. Beyond these challenges, the COVID-19 pandemic has created opportunities to understand the politics of fear and isolation, as well as political activity in light of additional barriers to political engagement. The onset of the COVID-19 pandemic forced states, localities, and their voters to adapt to an ever-changing, and worsening, public health crisis, all while the 2020 presidential season began to gain momentum. The pandemic added new obstacles to voting including the inability to physically cast a vote in person, the need to learn a new means of voting, and the necessity for additional precautions in the process.

The partisan shades of the COVID-19 pandemic cannot be ignored. There are distinct differences in the initial steps taken by Democratic and Republican-controlled states to prevent the spread of the virus and compliance with lockdown orders (Camobreco and He 2021). How the public views the pandemic, its urgency, and its veracity are also associated with partisan identification (Green et al. 2020; Gadarian, Goodman and Pepinsky 2021). But, there are many ways in which the COVID-19 pandemic, though experienced by all Americans, has exposed other divisions within the country, particularly those of a racial nature. For example, in half of the country the majority of Medicaid beneficiaries are people of color (Michener 2021). The holes in coverage among states has blatantly exposed as the pandemic has swept across the country and sent millions of Americans to seek testing, vaccinations, and medical attention. We suggest that the pandemic had electoral implications, also falling along racial lines, that may not be apparent at first glance.

Given what is a demonstrated difference in public opinion on the pandemic, as well as noted racial disparities in health and other outcomes in its wake, we are interested in the pandemic's racially-tinged implications for electoral participation. In Georgia, the announcement of a COVID-19 state-of-emergency came on March 14, 2020. On that same day, an announcement came from the Georgia Secretary of State, Brad Raffensperger, that the Georgia presidential preference primary originally slated for March 24, 2020 was rescheduled to 
May 19, to coincide with the regularly scheduled state and congressional primaries. Early in person voting for the presidential primary, which had begun on March 2, was halted effective at the end of the day on March 14, to resume at an unannounced date closer to May $19 .^{2}$

In subsequent days and weeks, the severity of the pandemic became more readily apparent. Recognizing the continuing risks posed by in person voting, Secretary Raffensperger announced on March 24 that every registered Georgia voter would receive an absentee ballot request form in the mail. This marked a dramatic shift from past elections, and the Secretary of State's office acknowledged that: "In the 2016 and 2018 November elections, around 95 percent of Georgia voters opted to cast their ballot in person versus the 5 percent who did so by mail." 3 This decision set-up the May primary election for record numbers of absentee-by-mail voters.

In addition, on April 9, citing concerns that Governor Kemp's extension of the pandemic state-of-emergency would limit opportunities to vote in person, Secretary Raffensperger ordered the now combined presidential, federal, and state primaries rescheduled to June 9. This new date stuck - the last day to register to vote for the June presidential primary was May 11 and early in person voting for the combined primaries began on May 18 and ran through June 5.

Secretary Raffensperger's acknowledgement of the need to support mail-in-voting was a stark change for a state whose voters overwhelming went to the polls in person. However, this came alongside another recognition: this new form of voting risked "disproportionately disenfranchis[ing] Black, Latino, and young voters." 4 While some work has suggested that transitions to all mail-in-voting in other states have a positive effect on the turnout of

\footnotetext{
2 "Georgia postpones presidential primary originally scheduled for March 24." March 14, 2020. CBS News.

3 "Raffensperger Takes Unprecedented Steps to protect Safety and Voter Integrity in Georgia." April 10, 2020. Georgia Secretary of State Office.

4 “ 'It Was Very Chaotic': Long Lines, Voting Machine Issues Plague Georgia Primary." June 9, 2020. Stephen Fowler. National Public Radio.
} 
people-of-color (Bonica et al. 2021), when given the option of how to vote, there is evidence to suggest that African-Americans will continue to choose in person. In particular, this stems from histories of voter suppression that were designed to disenfranchise Black voters (Parker and Towler 2019). This suppression was certainly notable in the state of Georgia (Mickey 2015). ${ }^{5}$ We believe that this will be apparent in the manner in which Black Georgians chose to cast their vote in the 2020 primaries. Moreover, during the early voting period and on primary day, polling places in the state saw incredibly lengthy lines and wait times to vote, especially at polling places that predominantly served non-white voters. ${ }^{6}$ Research has shown, however, that African-Americans, and specifically Black women, are willing to wait longer to vote than members of other racial groups. ${ }^{7}$ Therefore, even under these circumstances, we hypothesize that Black primary voters were more likely to cast ballots in person than white Democratic primary voters were in 2020.

Hypothesis 1: Black primary voters were more likely to vote early in-person than white primary voters.

If Black primary voters were more likely than white primary voters to vote early inperson, it stands to reason that they were also less likely to shift to voting by mail than white Democrats. Therefore, Hypothesis 2 presents what appears to be a corollary of Hypothesis 1 regarding racial differences in mail voting rates.

Hypothesis 2: Black primary voters were less likely to shift to mail voting than white primary voters.

\footnotetext{
${ }^{5}$ For example, see the 1958 Georgia State Voter Registration Test.

6 "Why Do Nonwhite Georgia Voters Have To Wait In Line For Hours? Too Few Polling Places." October 17, 2020. Stephen Fowler. National Public Radio.

7 "Black women are willing to wait longer in line to vote than any other demographic group." April 22, 2021. Costas Panagopoulos. Monkey Cage Blog. Washington Post.
} 
Yet Hypothesis 2 does not necessarily follow from Hypothesis 1. The number of Black primary voters could have increased overall relative to whites, which is plausible given the targeted mobilization of Black voters and shifting partisan proclivities of whites in Georgia. Moving to the general election, concerted efforts to ensure voters of color (and Black voters in particular) understood how to vote by mail and national attention on Republican resistance to mail-in voting may have eliminated a racial difference in vote-by-mail rates. Finally, we could imagine that racial differences in vote-by-mail adoption are the result of regional differences in the availability of early voting, dropboxes, county election administration, or any of the other within-state differences in election administration that are correlated with the race of the voter. Therefore, our tests are important for clarifying racial differences in both continued use of in-person voting and the shift to voting by mail among voters.

\section{Protesting in a Pandemic}

As some Americans lingered in lockdowns and quarantines, others gathered in record numbers to protest during the summer of 2020. This unprecedented mobilization saw millions of Americans advocating racial justice, denouncing police brutality, and crying "Black Lives Matter." As these protests grew and spilled over into more violent activism in Georgia, it was not only protesters who took to the streets. On May 29, 2020, Governor Brian Kemp declared a state of emergency in Fulton County, Georgia (Atlanta), later extending the order to all counties in the state and mobilizing the Georgia National Guard to maintain order (Executive Order 05.29.20.01; 05.30.20.01; 05.30.20.02). ${ }^{8}$

The national scale of these racial justice protests opened the door for continued research in the area of protest mobilization and specifically surrounding BLM and police violence (Bonilla and Tillery 2020; Jefferson, Neuner and Pasek 2020; Reny and Newman 2021). However, in spite of this mobilization, research has found that the events which triggered

\footnotetext{
${ }^{8}$ Available at: https://gov.georgia.gov/executive-action/executive-orders/2020-executive-orders
} 
these protests, and the protests themselves, have minimal impacts on public opinion, particularly among white Americans (Walker, Collingwood and Bunyasi 2020; Reny and Newman 2021). Less is known, however, about how these protests may have encouraged or discouraged political engagement, specifically electoral activity in 2020. Even less is known about their underlying implications that may fall along racial lines.

Drawing on Gillion (2020), we recognize the links between protest events and electoral politics. Protest activity draws attention to political issues and creates social pressure to join in. Gillion (2020) finds that even though Black voter turnout declined across the nation in 2016 when compared to prior presidential election, congressional districts that experienced higher numbers of BLM protests also saw higher voter turnout. A related literature, which has noted the power of protest to agenda-set and influence public opinion, has also indicated the ways in which minority-led protest has long-term (Mazumder 2018) and shorter-term (Enos, Kaufman and Sands 2019; Gillion 2020; Lee 2002; Wallace, Zepeda-Millán and JonesCorrea 2014; Wasow 2020) consequences for the attitudes and behaviors of those proximate. Take for example, the 1992 Rodney King uprisings in Los Angeles, California. These events increased political mobilization in the surrounding areas, most notably increasing the rate of registration among African-American voters (Enos, Kaufman and Sands 2019). Addressing the topic from another perspective, research in political psychology has noted that Black people are less likely to express political anger (Phoenix 2019). When they do, however, that anger is often channeled toward political activities that are related to their racial group. Banks, White and McKenzie (2019), for instance, find that Black people exposed to politically angering messages express greater willingness to make a donation to a Black organization and engage in protest activity.

We expect a similar parallel between racial justice protests and 2020 Georgia primary turnout. Drawing from this work, we set the expectation that 2020 racial justice protests may have increased African-American voter turnout, but depressed the participation of white 
Georgians.

Hypothesis 3A: The likelihood of African-Americans voting early in the June 2020 primary increased after racial justice protests began in Georgia, as compared to white voters.

However, there is also reason to expect that circumstances around protest, including the prominence of Black people engaging in political activity, could also have instead stirred white Georgians to political engagement. Therefore, we set competing expectations about responses to racial justice protests in Georgia and across the nation. Scholars of Southern politics have long theorized about the "racial threat" that growing populations of Black people pose to the whites around them (Key 1949). This threat spurs white voters to higher rates of political participation and toward more conservative political preferences in defense of their status as a majority racial group (Blalock 1967). Other actions deemed threatening, including protest and even the mere presence of Black people, have noted implications for the political behavior of white people (Enos, Kaufman and Sands 2019; Mazumder 2018). Drawing from this literature, we propose a competing hypothesis to the one set forth above. The racial "threat" posed by Black protesters calling for an end to racial injustices and white supremacy, and at times the abolition of the police may have also prompted whites to turn out to vote in higher numbers during the primary's early voting period.

Hypothesis 3B: The likelihood of white voters voting early in the June 2020 primary increased after racial justice protests began in Georgia, as compared to Black voters. 


\section{Data and Approach}

We test our expectations by examining two periods of time that mark crucial points in the COVID-19 pandemic and racial justice protests in 2020. To do this, we draw on the Georgia statewide voter registration list and voter history files. The voter registration list contains personal information about registered voters in Georgia, including demographic information, like gender and racial self-identification, as well as their date of registration and county of residence. ${ }^{9}$ The voter history files are organized by election, and include data on who voted overall in primary, general, and/or special elections. We augment the voter history data with the publicly available Georgia Absentee File, which distinguishes between early in person voters and absentee-by-mail voters. Importantly, the Absentee File also allows us to observe the day in which early in-person voters voted, the day vote-by-mail ballots were tallied, or the day mail ballots were picked up from dropboxes; combined with information about who voted in-person on election day, we can observe the day each voter "voted." 10 Overall, we have data on 1,460,961 Democratic primary voters in 2020, approximately 494,000 of whom were White $(34 \%)$ and 860,000 Black $(58.9 \%){ }^{11}$

We consider two periods of time in order to test our expectations. The first interval, testing Hypotheses 1 and 2, includes the time span between February 14, 2020 12 and June 9,

\footnotetext{
${ }^{9}$ The Georgia voter registration list is available for purchase through the Georgia Secretary of State's office for a fee of $\$ 250.00$. Over $90 \%$ of 2020 voters in Georgia self-identified their race when registering to vote. For the remainder, we use the wru package in $\mathbf{R}$ to compute the probability each remaining voter is White, Black, Hispanic, or Asian, and then sum the probabilities across all non self-identifying individuals to estimate the number of Black and White voters who did not self-identify. Exclusion of voters with probabilistic race information does not have a substantive impact on our conclusions.

${ }^{10}$ Lags in reporting likely vary systematically by vote mode, as mail-in ballots sent via the postal service were likely placed in a mailbox 1-3 days prior to receipt by counties. However, these lags do not appear to change our substantive conclusions.

${ }^{11}$ We focus on Democratic primary voters in an attempt to account for partisan differences in both propensity to vote in the primary elections (Democrats initially had competitive elections for President and both U.S. Senate seats, while Republicans only had a single competitive U.S. Senate seat) and emergent polarization regarding the use of mail ballots. However, our general conclusions regarding racial differences in primary vote mode hold when including Republican primary voters.

${ }^{12}$ February 14 is the first day with a significant number of absentee-by-mail ballots recorded by counties across the state. However, ballots counted before that date are included in the cumulative sums that we rely
} 
2020, the final, rescheduled date of the combined presidential, senatorial, and state primary elections.

We test Hypotheses $3 \mathrm{~A}$ and $3 \mathrm{~B}$ over a period of time that saw the rapid increase of racial justice and BLM protests in Georgia. This period begins on May 29, 2020, the first day of large scale protests in Georgia and an evening where "looting and unrest" in downtown Atlanta precipitated the declaration of a state of emergency for Fulton County (May 29) and extension of the emergency to the entire state, plus activation of the Georgia National Guard, by Governor Brian Kemp on May 30. ${ }^{13}$ Through the weekend, protests spread across the state, though by June 3 protest activity had begun to wane and the state reported making no arrests between Friday, June 5 and Sunday, June 7. On June 8, Governor Kemp indicated the state of emergency would expire at the end of the day. As our interest is in capturing the impact of highly visible protest activity, our time period ends on June 3, 2020. ${ }^{14}$ This spike in protest activity is shown in Figure 1.

\section{Results}

\section{A Pandemic-induced Racial Divide in (Method of) Voting}

We begin by examining the impact of the COVID-19 pandemic on Black and White voting in the 2020 primary elections. As noted above, the presidential preference primary was originally scheduled for March 24, 2020, and other federal and state primaries were scheduled for May 19, 2020. However, after voting in the presidential primary began, Secretary Raffensperger halted early in-person voting, delayed the presidential primary, mailed all Georgians absentee-by-mail ballot request forms, then delayed both sets of primaries again

on in testing Hypotheses 1 and 2.

${ }^{13}$ https://www.ajc.com/news/crime-law/atlanta-protests-11th-day-kemps-ends-national-guardinvolvement/nAteRwHGRHhatU5Cd8vXkK/

${ }^{14}$ Inclusion of data on June 4 or June 5 does not change our substantive conclusions, though because of a surge in last-minute early voting on the final days it was available we lose precision in our estimates 


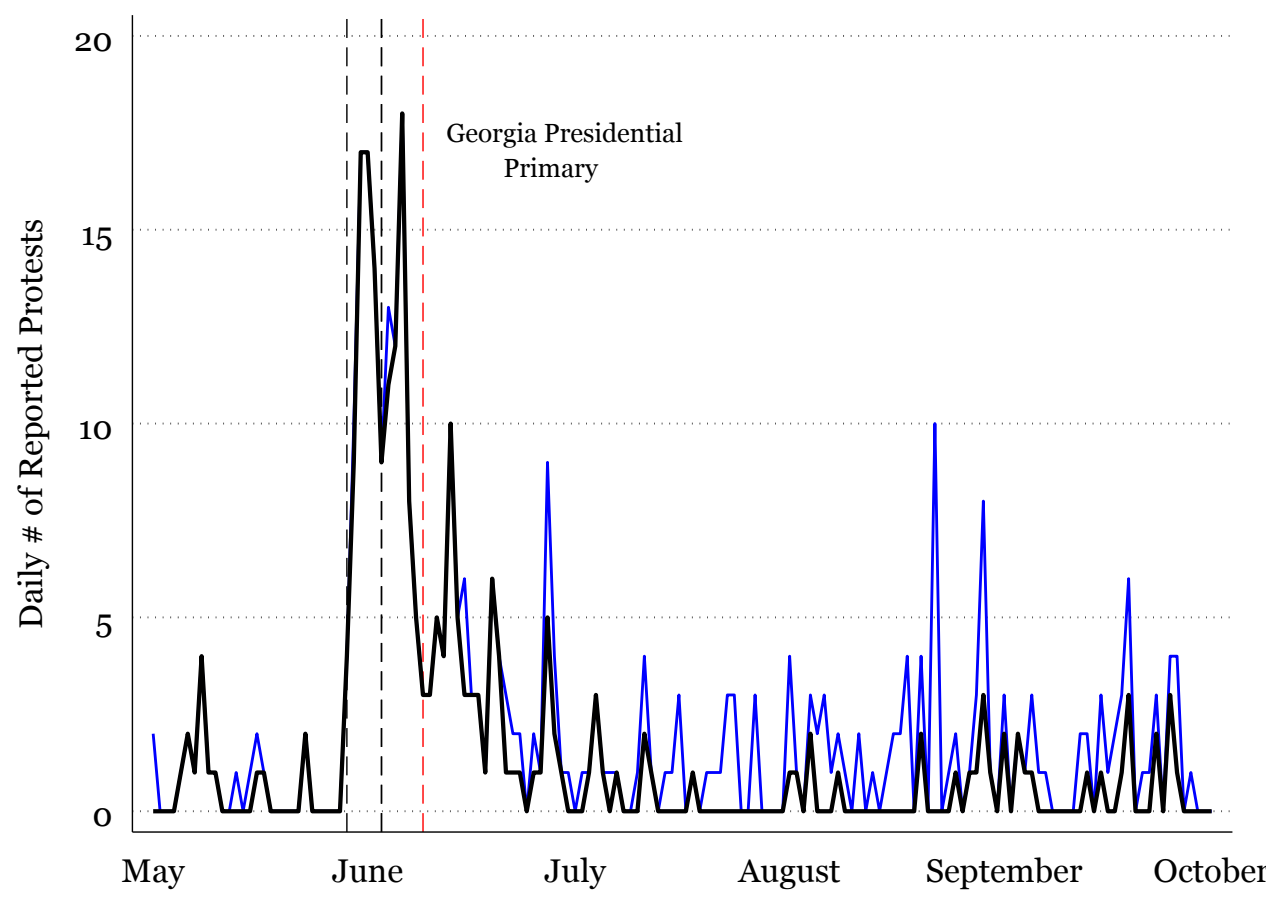

Figure 1: Georgia Statewide Protest Activity. Figure shows the total number of protests (blue line) and racial justice-related protests (black line) reported across the state of Georgia between May 2020 and October 2020. Racial justice protests sky-rocket the week of May 25, 2020 in the wake of the murder of George Floyd's murder in Minneapolis, Minnesota. We consider early-voting in relation to protests between May 29 and June 3, 2020, a period indicated by the black dotted lines in the figure. June 9, 2020, the date of the Georgia presidential primary, is noted with the red dotted line. (Observations from the Armed Conflict Location and Event Dataset (Raleigh et al. 2010).

to June 9, 2020. In a state where over $90 \%$ of voters cast ballots in person, and the Black community traditionally used early in-person voting as a key part of grassroots mass mobilization efforts, the pandemic and the Secretary's response to the pandemic had the potential to exacerbate racial disparities in political participation.

The measurement of turnout rates in partisan primary elections is notoriously difficult, as it is difficult to define the pool of potential partisan voters (Norrander, 1986). In Figure 2, we provide two intersecting ways of thinking about Black and White turnout in the 2020 Georgia Democratic Primary over the roughly four months the election was held. First, the 


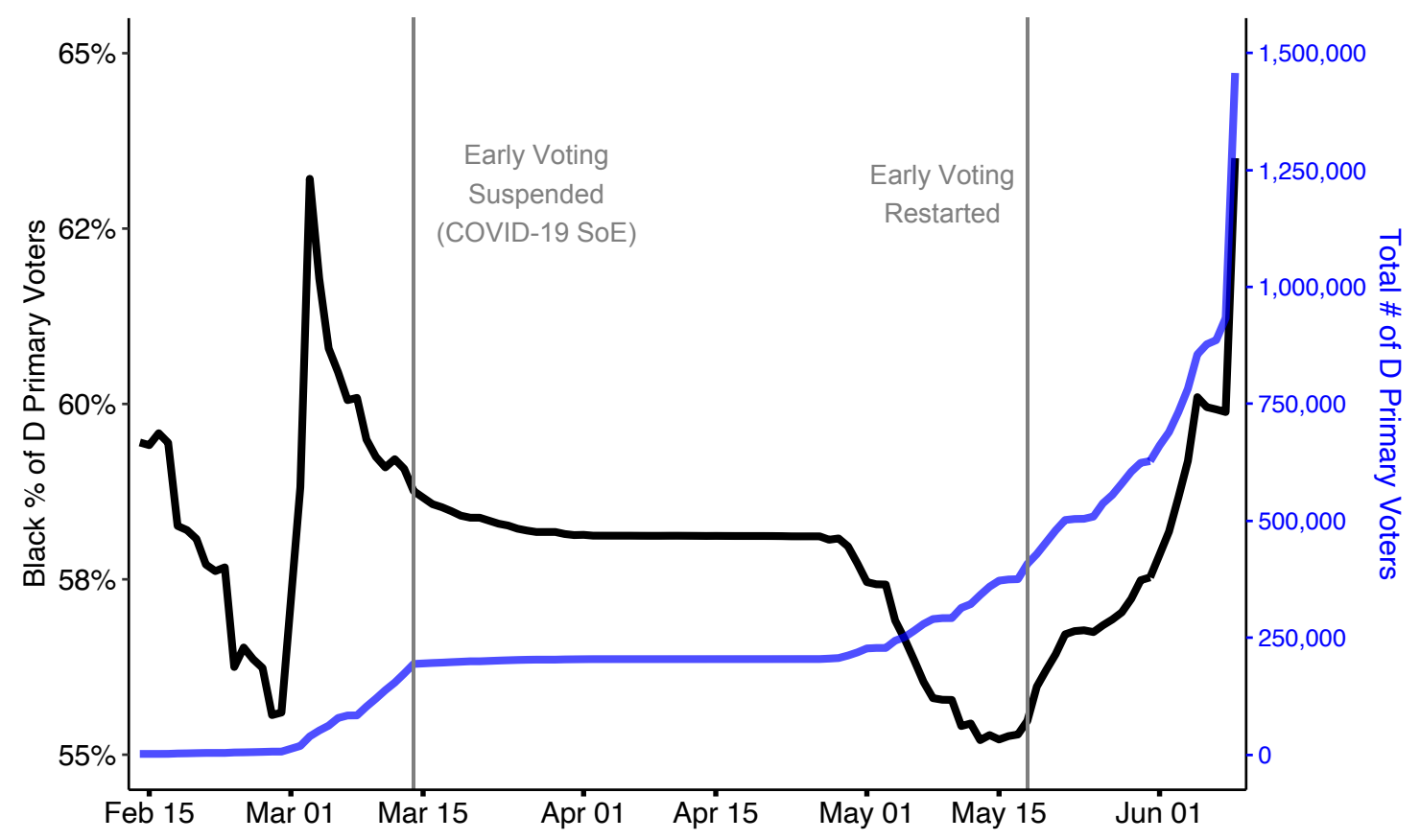

Figure 2: 2020 Georgia Democratic Primary Turnout and Black Voteshare. Figure indicates the percent of Black and non-Hispanic white voters in the 2020 Democratic Primary elections who were Black (black line) and the total number (cumulative sum) of Democratic Primary voters (blue line) as of the date indicated. Early in person voting in the primary was suspended on March 14, when a COVID-19 state of emergency was declared in Georgia. Early in person voting was restarted on May 18.

solid black line and scale on the left y-axis indicates the cumulative share of Democratic Primary voters who were Black as a percent of the total number of Black or non-Hispanic White Democratic primary voters as of the date indicated on the x-axis. This measure compares cumulative turnout for Black and White Georgians. Second, the solid blue line and right $\mathrm{y}$-axis scale indicates the total number of voters of any race in the Democratic primary over time. ${ }^{15}$

We also indicate two key dates in Figure 2. Early in-person voting for the Democratic Presidential Preference primary began on March 3, but Governor Kemp declared a COVID19 state of emergency on March 14. On the same day, Secretary Raffensperger halted all

\footnotetext{
${ }^{15}$ Over $90 \%$ of Democratic primary voters were non-Hispanic White or Black. We include disaggregated data on Hispanic and Asian American primary voters later in the analysis.
} 
in person voting. We note the date early voting was suspended in the figure. However, absentee-by-mail ballots continued to trickle in, though voter turnout changes only slightly until absentee ballots for the rescheduled, combined primary elections were mailed out in late April and begin to be counted en masse on April 27. Then, on May 18, early in-person voting was restarted in advance of the rescheduled June 9 primary date. We indicate this date in Figure 2 as well.

Figure 2 indicates that the availability, or lack thereof, of early in-person voting is associated with the waxing and waning of Black turnout in the primary elections, relative to white turnout. Early in the primary, when mail-in ballots were the only form of voting that could be counted, the share of Democratic primary voters who were Black decreased over time. However, as the blue line indicates there were a tiny number of voters during this period: approximately 10,000 Georgians cast ballots in the Democratic primary before early in-person voting opened on March 3. The next day, Black voters turned out in large numbers and boosted Black turnout (relative to whites) to the highest level we would see prior to election day.

Georgia had its first COVID-19 positive tests on March 2, but concerns over COVID-19 had already spread throughout the country. Some voters may have stayed home or decided to switch to mail ballots prior to the March 14 suspension of early in-person voting, and the limited availability of absentee balloting in Georgia means that analysis of this earlier period is not definitive. However, the dedication to in person voting among Black Democrats is more clear as the percent of Black Democratic primary voters sharply decreases before early in person voting resumes on May 18. Black turnout is at its lowest percentage of the primary electorate immediately prior to this date, as white Georgians were disproportionately likely to shift to mail balloting. The Black share of Democratic primary voters increases at a faster rate than the number of primary voters overall until the weekend prior to election day (when early in-person voting ceased) before jumping again based on in-person voters on June 9. 
The results in Figure 2 coincide with Hypotheses 1 and 2. Without the option to cast votes in person, it seems plausible that the Black share of primary voters would be significantly lower, even placed within the context of the COVID-19 pandemic. As a result, the Black share of primary voters was negatively impacted by the large-scale shift to vote-bymail in the state, as Black Democratic voters were less likely to adopt vote-by-mail than white Democratic voters.

That said, Black voters represented the majority of 2020 Democratic primary voters during the entire period the primary was held, and their votes cast out-paced those of white Democratic voters in the both early in person and absentee-by-mail methods. Figures 3 and 4 show that most of this advantage, and all of the advantage prior to the COVID-19 state of emergency, was due to a persistent Black advantage in in person early votes. In Figure 3, we see that once early in-person voting begins on March 3, the Black share of early in-person votes cast in the Democratic primary increases steadily along with the number of early in-person voters in the time prior to the suspension of early voting in March. It increases further after early-voting resumes in early May. By April 15, when primary ballot counting stops (both mail and early in person), about nine times as many Black voters had voted early in person as had voted by mail.

Black Democratic voters' inclination for early in person voting in comparison to white voters is even more apparent when comparing between the two methods in Figure 4. While a greater number of Black Democrats ultimately cast their ballot by mail than in person, the distinction between the two methods is starker among white Democrats, who overwhelmingly cast their early ballots by mail. Before the pandemic, neither white nor Black voters frequently voted by mail, but slightly more Black voters voted by mail than white voters before March 8. That trend is reversed, though, leading up to the COVID state-of-emergency on March 14. Even after early voting was suspended, white Democratic voters held an advantage in mail-in voting. Since Black voters made up about $63 \%$ of Democratic primary voters 

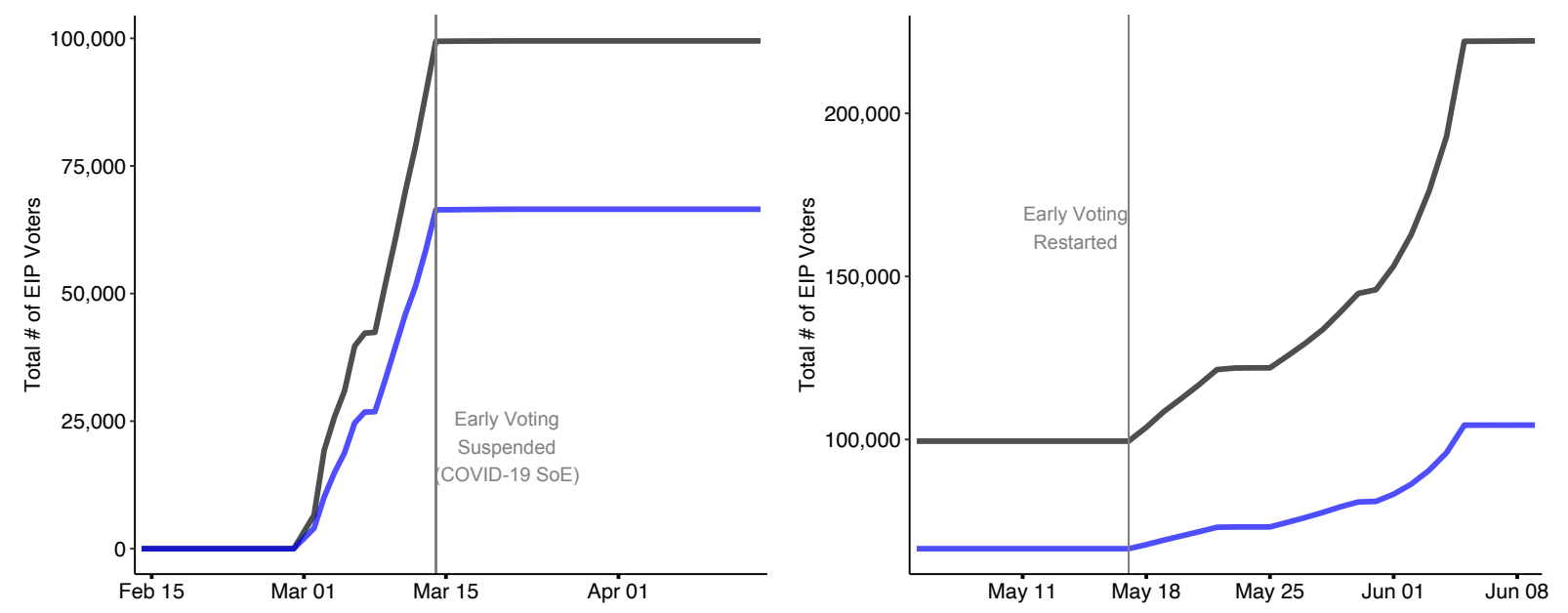

Figure 3: 2020 Georgia Democratic Primary Early in person Votes by Race. Figure indicates the cumulative number of Black (black line) and non-Hispanic white (blue line) early in person voters in the 2020 Democratic Primary elections. While Black, early in person voters outnumbered non-Hispanic white, early in person voters prior to the suspension of early-voting, this distinction becomes even more substantial after early in person voting resumes.
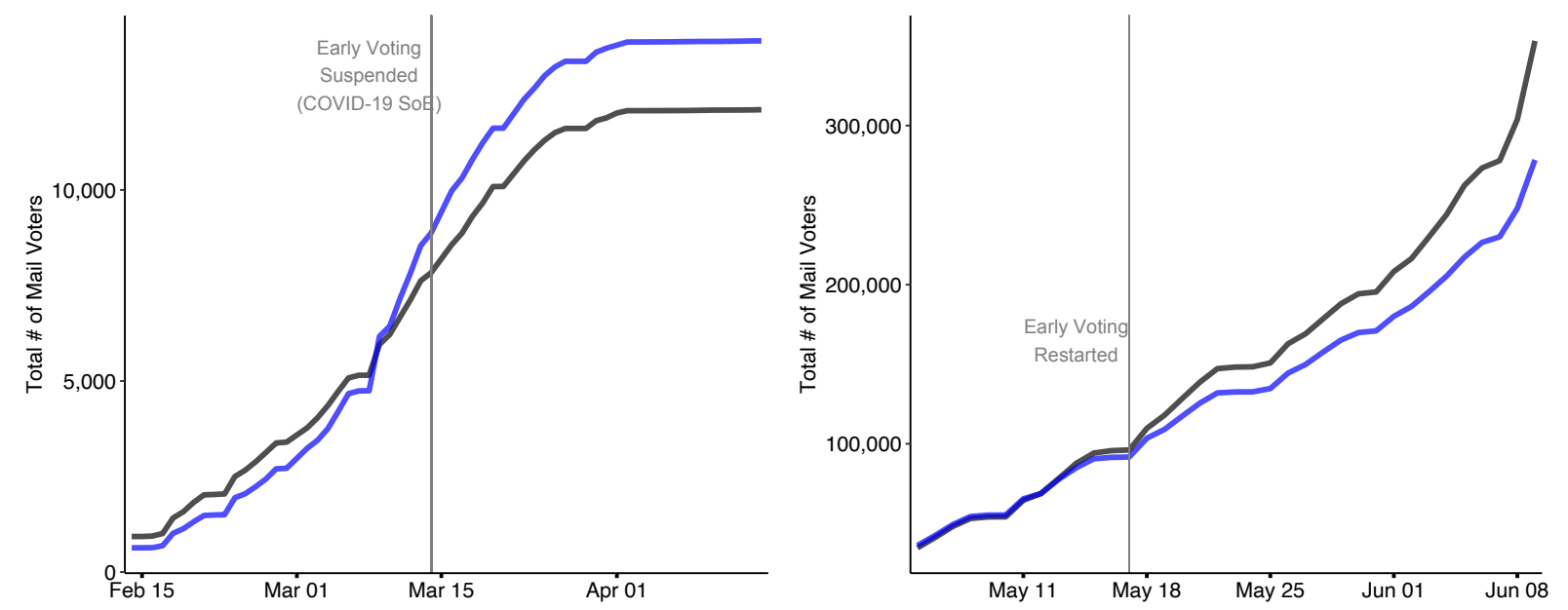

Figure 4: 2020 Georgia Democratic Primary Absentee-by-Mail Votes by Race. Figure indicates the cumulative number of Black (black line) and non-Hispanic white (blue line) voters voting by mail in the 2020 Democratic Primary elections. Dates represent date ballots were recorded by counties.

overall, this advantage is quite notable and indicates a clear racial divide in vote method as vote-by-mail emerged as a viable (and state supported) option for all Georgians. By May, 
Black mail-in voting had surpassed that of white voters, but still the share of Black by mail voters was far less than the Black share of primary voters overall. Thus, the patterns in Figure 3 and Figure 4 strengthen the case for $\mathrm{H} 1$ and $\mathrm{H} 2$ already made in Figure 2.

Election day on June 9, 2020 was described as "unacceptable," "a catastrophe," and "a disaster" by leaders from both parties due to long lines in heavily-minority areas. ${ }^{16}$ After this debacle, calls to encourage mail-in voting became even louder. Did a preference by Black voters for in-person voting over vote-by-mail linger into the general election? To examine this question, we consider racial differences in the shift to vote-by-mail in the November election among the population of those voting in person in the "unacceptable" 2020 Democratic primary.

Table 1 shows that a significant difference in the rate of voting in the general election exists between white and Black Georgians. Among voters who previously voted in the June primary, the share of Black voters turning out to vote at all was about one percentage point less than the share of white voters who voted. But, when we subset this population to consider only those voters who previously voted in the June 2020 primary and also voted by mail in the general election, it becomes apparent that the gap significantly widens. The rate of absentee-by-mail voting for Black Georgians is six percentage points less than that of white voters in the general election. This suggests that not only were Black voters slower to adopt voting by mail amidst the shifting June 2020 primary, but, by November, they still had not adopted the process to the same degree that white voters had.

In fact, the second model in Table 1 shows that this expressed preference for in-person voting was so much stronger among Black Democratic primary voters (and other primary voters of color) than white Democratic primary voters that turnout at all in November was slightly, but significantly lower for in-person primary voters of color than in-person white

\footnotetext{
${ }^{16}$ https://www.nbcnews.com/politics/2020-election/georgia-secretary-state-launches-investigation-afterunacceptable-voting-problems-n1228541
} 


\begin{tabular}{lcc}
\hline & \multicolumn{2}{c}{ Dependent Variable: } \\
\cline { 2 - 3 } & Voted by Mail & Voted (Any Method) \\
& $(1)$ & $(2)$ \\
\hline Black & $-0.061^{*}$ & $-0.011^{*}$ \\
& $(0.001)$ & $(0.001)$ \\
Latinx & $-0.044^{*}$ & $-0.025^{*}$ \\
& $(0.002)$ & $(0.001)$ \\
Asian & $0.080^{*}$ & $-0.015^{*}$ \\
& $(0.003)$ & $(0.002)$ \\
Intercept & $0.120^{*}$ & $0.950^{*}$ \\
& $(0.014)$ & $(0.008)$ \\
\hline County FEs & $\checkmark$ & $\checkmark$ \\
Dems Only & $\checkmark$ & $\checkmark$ \\
N & 695,048 & 695,048 \\
R-squared & 0.017 & 0.003 \\
\hline
\end{tabular}

Table 1: Racial Differences in 2020 General Voting for in person 2020 Primary Voters. Dependent variable in Model 1 is voting by mail in the November 2020 General election, dependent variable in Model 2 is voting at all in the November 2020 General. Includes only registrants who voted in the 2020 Georgia Primary. Excluded category is non-Hispanic white voters. ${ }^{*} \mathrm{p}<.05$

primary voters. Of course, the vast majority of in-person Democratic primary voters (9295\% across all racial/ethnic groups) turned out in November. However, the small share that did not were disproportionately Black, Latinx, or Asian. 


\section{Racial Justice Protests and Black Turnout}

At the tail end of the rescheduled 2020 primary elections, shock over the murder of George Floyd led to protests and militarized police responses in several areas of Georgia. While starting on the evening of May 29 in Atlanta, by May 30 protests had spread throughout the state. With Governor Kemp declaring a "continued and expanded threat of unlawful assemblages of persons, violence, overt threats of violence, danger to persons and property, and disruption of the peace and tranquility in the State of Georgia," conditions were ripe for this non-electoral mobilization to impact voting behavior. With this in mind, we outlined two competing hypotheses regarding Black-White turnout differentials during the period of intense protest activity: a relative increase in Black turnout during the period (Hypothesis $3 \mathrm{~A}$ ) or a racial threat-induced relative increase in White turnout during the period (Hypothesis $3 \mathrm{~B})$.

273,111 individuals voted during the 5-day period from May 29 to June 3, 2020, in either party's primary, roughly $11 \%$ of all primary voters in the state. Table 2 presents regression estimates using the voter file, vote history, and absentee data where the dependent variable is, conditional on voting at all in the primaries, whether the voter cast a ballot during during or immediately after the protests. In Model 1, which uses county fixed effects to account for county-by-county variation in the availability of early voting, vote recording differences, and county-level demographic differences that may be correlated with turnout, we see that there was a significantly higher likelihood that Black voters who voted at all during the primary turned out during the protest period as compared to white voters and voters of other racial groups. ${ }^{17}$ This provides evidence for Hypothesis 3A.

To gain a more accurate measure of who is most impacted by the protests, and further clarify potential mechanisms, we employ a number of additional specifications, displayed in

\footnotetext{
${ }^{17}$ Notably, Latinx and Asian American primary voters were less likely to turn out during the protest period than whites as well. This may offer some evidence of Hypothesis 3B operating, but not to the extent that mechanisms associated with Hypothesis 3A activated Black voters.
} 


\begin{tabular}{|c|c|c|c|c|c|c|}
\hline & \multicolumn{4}{|c|}{ Baseline Specifications } & \multirow{2}{*}{$\begin{array}{c}\text { Only } 16 / 18 \\
\text { D Voters } \\
(5)\end{array}$} & \multirow{2}{*}{$\begin{array}{c}\text { Age/Gender } \\
\text { Controls } \\
(6)\end{array}$} \\
\hline & $(1)$ & $(2)$ & $(3)$ & $(4)$ & & \\
\hline Black & $\begin{array}{c}0.006^{*} \\
(0.000)\end{array}$ & $\begin{array}{c}0.039^{*} \\
(0.001)\end{array}$ & $\begin{array}{r}-0.001 \\
(0.001)\end{array}$ & $\begin{array}{c}0.037^{*} \\
(0.001)\end{array}$ & $\begin{array}{c}0.035^{*} \\
(0.001)\end{array}$ & $\begin{array}{c}0.033^{*} \\
(0.001)\end{array}$ \\
\hline Latin $x$ & $\begin{array}{r}-0.037^{*} \\
(0.002)\end{array}$ & $\begin{array}{r}-0.002 \\
(0.003)\end{array}$ & $\begin{array}{r}-0.044^{*} \\
(0.002)\end{array}$ & $\begin{array}{r}-0.001 \\
(0.004)\end{array}$ & $\begin{array}{c}0.011^{*} \\
(0.005)\end{array}$ & $\begin{array}{r}-0.003 \\
(0.005)\end{array}$ \\
\hline Asian & $\begin{array}{r}-0.027^{*} \\
(0.002)\end{array}$ & $\begin{array}{r}-0.023^{*} \\
(0.003)\end{array}$ & $\begin{array}{r}-0.034^{*} \\
(0.002)\end{array}$ & $\begin{array}{r}-0.018^{*} \\
(0.004)\end{array}$ & $\begin{array}{r}-0.010 \\
(0.006)\end{array}$ & $\begin{array}{r}-0.023^{*} \\
(0.006)\end{array}$ \\
\hline Intercept & $\begin{array}{c}0.096^{*} \\
(0.004)\end{array}$ & $\begin{array}{c}0.158^{*} \\
(0.007)\end{array}$ & $\begin{array}{c}0.092^{*} \\
(0.010)\end{array}$ & $\begin{array}{c}0.128^{*} \\
(0.016)\end{array}$ & $\begin{array}{c}0.135^{*} \\
(0.020)\end{array}$ & $\begin{array}{c}0.232^{*} \\
(0.020)\end{array}$ \\
\hline County FEs & $\checkmark$ & $\checkmark$ & $\checkmark$ & $\checkmark$ & $\checkmark$ & $\checkmark$ \\
\hline Early Only & & $\checkmark$ & & $\checkmark$ & $\checkmark$ & $\checkmark$ \\
\hline Dems Only & & & $\checkmark$ & $\checkmark$ & $\checkmark$ & $\checkmark$ \\
\hline $\mathrm{N}$ & $2,379,561$ & $1,439,269$ & $1,226,305$ & 718,756 & 468,071 & 468,071 \\
\hline R-squared & 0.005 & 0.014 & 0.005 & 0.015 & 0.016 & 0.019 \\
\hline
\end{tabular}

Table 2: Racial Differences in 2020 Georgia Democratic Primary Voting during Racial Justice Protests. Dependent variable is voting (either early in person or by mail) between May 29 and June 3, 2020. Includes only registrants who voted in the 2020 Georgia Primary. Excluded category is non-Hispanic white voters. ${ }^{*} \mathrm{p}<.05$

Table 2. The protest period takes place during the tail end of early voting, and less than a week before voters could choose to go to the polls in person on election day. However, Black voters were far more likely than White voters to turn out on election day in the Democratic primary. Thus, in most of our specifications we only consider the likelihood of turnout among those primary voters who voted early. In these specifications, we see a much larger difference between Black primary voters and White primary voters, on the order of 3.3-3.9 percentage points. We also subset the data to Democratic primary voters only in most models. While in theory White Republican primary voters may have been more susceptible to the "racial threat" response to the protests, we see that if we only examine Democrats the Black-White difference in likelihood of voting during the protest period drops to 0 in Model 3 , despite 
staying large and statistically significant for the Black-Latinx and Black-Asian difference. Recalling the large number of Black voters voting on election day, however, we interpret this finding to indicate that (a) racial threat is not operating for White Republicans in a manner that increases turnout during the protest period, and (b) the Black preference for in-person voting extended to election day.

Models 4, 5, and 6 in Table 2 combine these subsetting strategies. In Model 5, we also subset to voters who voted in a Democratic primary in 2016 or 2018. Surprisingly, we continue to see a large and significant racial difference even among the "habitual" primary voters. Finally, in Model 6 we subset the data as in Model 5, and add control variables for voter age and self-reported sex. Again, the core result is robust, despite the fact that both of these variables are correlated with race. Taken together, therefore, we find strong evidence for Hypothesis 3A with voter race being the key factor driving the difference between Black and White turnout timing.

\section{Discussion and Conclusion}

Analyzing racial differences in who voted in 2020, we can confirm our core hypotheses. Black voters in Georgia had a sustained preference for casting their ballots in person (Hypothesis 1), even as the COVID-19 pandemic continued to devastate the country and a broad shift to mail balloting took place (Hypothesis 2). This inclination lasts through the general election, where the difference in the share of white and Black voters (given they voted in the primary election) widens from one percentage point, when considering both in person and vote-by-mail ballots, to six percentage points, when considering only vote-by-mail.

Second, there is also evidence in support of Hypothesis 3A, in which we expected racial justice and BLM protests in May and June 2020 energized Black citizens to turnout to vote. Black Georgians had a higher likelihood of turning out to vote than white Georgians 
during the five days immediately following the on-set of the protests. This, therefore, refutes our alternative hypothesis (H3B), in which we proposed that racial threat surrounding the massive protests may have spurred white voter turnout. Our findings have several important implications that speak to the need for further exploration and scrutiny of the vote-by-mail process. First, this work reflects on the habit-forming nature of voting (Coppock and Green 2016; Gerber, Green and Shachar 2003). The act of voting itself is reinforced over time those who have voted in the past are more likely to do so in the future. Voting is habitforming, and our work suggest that this extends not only to the action itself, but to the method by which it is undertaken. Therefore, someone who has voted in person in the past, particularly African-American voters within this paper's context, are more likely to continue with that method. We see that this habit endures even with an elevated public health risk and the chance of long lines and hour long waits to cast a vote in person. It seems that Georgia's Black voters were more likely to place themselves in harm's way to vote in a pandemic, taking on additional challenges to cast their ballots.

In light of the inclination for in person voting over vote-by-mail among African-Americans, these finding should also give pause to calls for wide spread transitions to voting by mail. Particularly so within the Democratic Party, for whom African-Americans comprise the majority of the Democratic electorate in Georgia. The findings in this paper indicate that such reforms may create a double-burden for Black voters, rather than serve as a more universally inclusive and accessible entry point to electoral politics. Black voters must either adapt to this new system and gain trust in it or face barriers to entry like limited polling locations and long wait times. Even as the likelihood of Black voter turnout increased during the protest period between May 29 and June 3, 2020, at no point in that period of time does a greater share of Black Georgians vote by mail rather than in person. The outcome, particularly in the absence of mobilizing protests or an election with weight of the 2020 presidential contest, could plausibly be attrition of Black voters in the future. Our research suggests that the 
willingness to shift to mail-in voting is not uniform across the electorate. Consequently, a shift to voting by mail, which has been championed as a democratic reform to make the ballot more readily available, particularly among the Democratic Party, might not be as democratic as it appears. 


\section{References}

Banks, Antoine J, Ismail K White and Brian D McKenzie. 2019. "Black politics: How anger influences the political actions Blacks pursue to reduce racial inequality." Political Behavior 41(4):917-943.

Blalock, Hubert M. 1967. Toward a theory of minority-group relations. New York: Wiley.

Bonica, Adam, Jacob M Grumbach, Charlotte Hill and Hakeem Jefferson. 2021. "All-mail voting in Colorado increases turnout and reduces turnout inequality." Electoral Studies $72: 102363$.

Bonilla, Tabitha and Alvin B Tillery. 2020. "Which identity frames boost support for and mobilization in the\# BlackLivesMatter movement? An experimental test." American Political Science Review 114(4):947-962.

Burch, Traci. 2013. Trading Democracy for Justice: Criminal Convictions and the Decline of Neighborhood Political Participation. Chicago: University of Chicago Press.

Camobreco, John F and Zhaochen He. 2021. "The Party-Line Pandemic: A Closer Look at the Partisan Response to COVID-19." PS: Political Science 83 Politics pp. 1-9.

Coppock, Alexander and Donald P Green. 2016. "Is voting habit forming? New evidence from experiments and regression discontinuities." American Journal of Political Science 60(4):1044-1062.

Enos, Ryan D, Aaron Russell Kaufman and Melissa L Sands. 2019. "Can Violent Protest Change Local Policy Support? Evidence from the Aftermath of the 1992 Los Angeles Riot." American Political Science Review .

Fraga, Bernard L. 2018. The Turnout Gap: Race, Ethnicity, and Political Inequality in a Diversifying America. New York: Cambridge University Press. 
Gadarian, Shana Kushner, Sara Wallace Goodman and Thomas B Pepinsky. 2021. "Partisanship, health behavior, and policy attitudes in the early stages of the COVID-19 pandemic." Plos one 16(4):e0249596.

Gerber, Alan S, Donald P Green and Ron Shachar. 2003. "Voting may be habit-forming: evidence from a randomized field experiment." American journal of political science $47(3): 540-550$.

Gillion, Daniel Q. 2020. The Loud Minority. Princeton University Press.

Green, Jon, Jared Edgerton, Daniel Naftel, Kelsey Shoub and Skyler J Cranmer. 2020. "Elusive consensus: Polarization in elite communication on the COVID-19 pandemic." Science Advances 6(28):eabc2717.

Hajnal, Zoltan, Nazita Lajevardi and Lindsay Nielson. 2017. "Voter Identification Laws and the Suppression of Minority Votes." The Journal of Politics 79(2):363-379.

Highton, Benjamin. 2017. "Voter Identification Laws and Turnout in the United States." Annual Review of Political Science 20(1):149-167.

Jefferson, Hakeem, Fabian G Neuner and Josh Pasek. 2020. "Seeing Blue in Black and White: Race and Perceptions of Officer-Involved Shootings." Perspectives on Politics pp. 1-19.

Key, V.O. 1949. Southern Politics in State and Nation. New York: A.A. Knopf.

Lee, Taeku. 2002. Mobilizing public opinion: Black insurgency and racial attitudes in the civil rights era. Chicago: University of Chicago Press.

Mazumder, Soumyajit. 2018. "The persistent effect of US civil rights protests on political attitudes." American Journal of Political Science 62(4):922-935. 
Michener, Jamila D. 2021. "Politics, Pandemic, and Racial Justice Through the Lens of Medicaid.".

Mickey, Robert. 2015. Paths Out Of Dixie. New York: Princeton University Press.

Norrander, Barbara. 1986. "Measuring Primary Turnout in Aggregate Analysis." Political Behavior 8(4):356-373.

Parker, Christopher Sebastian and Christopher C Towler. 2019. "Race and authoritarianism in American politics." Annual Review of Political Science 22:503-519.

Pettigrew, Stephen. 2017. "The Racial Gap in Wait Times: Why Minority Precincts are Underserved by Local Election Officials." Political Science Quarterly 132(3):527-547.

Pettigrew, Stephen. 2021. "The Downstream Consequences of Long Waits: How Lines at the Precinct Depress Future Turnout." Electoral Studies 71:102188.

Phoenix, Davin L. 2019. The Anger Gap: How Race Shapes Emotion in Politics. New York: Cambridge University Press.

Raleigh, Clionadh, Andrew Linke, Håvard Hegre and Joakim Karlsen. 2010. "Introducing ACLED: an armed conflict location and event dataset: special data feature." Journal of peace research 47(5):651-660.

Reny, Tyler T and Benjamin J Newman. 2021. "The Opinion-Mobilizing Effect of Social Protest against Police Violence: Evidence from the 2020 George Floyd Protests." American Political Science Review First View.

Walker, Hannah L. 2020. Mobilized by Injustice: Criminal Justice Contact, Political Participation, and Race. New York: Oxford University Press. 
Walker, Hannah, Loren Collingwood and Tehama Lopez Bunyasi. 2020. "White Response to Black Death: A Racialized Theory of White Attitudes Towards Gun Control." Du Bois Review: Social Science Research on Race pp. 1-24.

Wallace, Sophia J, Chris Zepeda-Millán and Michael Jones-Correa. 2014. "Spatial and temporal proximity: Examining the effects of protests on political attitudes." American Journal of Political Science 58(2):433-448.

Wasow, Omar. 2020. "Agenda Seeding: How 1960s Black Protests Moved Elites, Public Opinion and Voting." American Political Science Review 114(3):638-659. 